\title{
Consequences of systemic venous drainage and denervation of heterotopic pancreatic transplants for insulin/C-peptide profiles in the basal state and after oral glucose
}

\author{
M. Nauck ${ }^{1}$, M. Büsing ${ }^{3}$, E. G. Siegel ${ }^{1}$, J. Talartschik ${ }^{2}$, A. Baartz ${ }^{3}$, T. Baartz ${ }^{3}$, U. T. Hopt ${ }^{3}$, H. D. Becker ${ }^{3}$ and \\ W. Creutzfeldt ${ }^{1}$ \\ ${ }^{1}$ Division of Gastroenterology and Endocrinology, ${ }^{2}$ Division of Nephrology and Rheumatology, Department of Medicine, \\ Georg-August-University, Göttingen and ${ }^{3}$ Department of Surgery, Eberhard-Karls-University, Tübingen, FRG
}

Summary. Plasma glucose, immunoreactive insulin and C-peptide concentrations were compared in nine pancreas-kidney-transplanted patients (systemic venous drainage) and in ten non-diabetic kidneytransplanted patients with similar kidney function. In the basal state, C-peptide (insulin secretion) was similar, but immunoreactive insulin was higher and glucose concentrations were slightly, but significantly lower in pancreas-transplanted patients. After $50 \mathrm{~g}$ oral glucose, the plasma glucose and IR-insulin profiles were similar in both groups. The circumvention of first-pass hepatic insulin extraction (decreased endogenous insulin clearance) was compensated for by a significant reduction in insulin secretion (C-peptide; $\mathrm{p}=0.036$ ). In conclusion, hyperinsulinaemia in pancreas-transplanted patients with systemic venous drainage is significant only in the basal state. Insulin delivered into the portal and peripheral circulation, when leading to similar insulin profiles, maintains comparable degrees of glucose tolerance.

Key words: Pancreas transplantation - Insulin secretion - C-peptide - Systemic venous drainage Insulin metabolic clearance

\section{Introduction}

Recently, pancreas transplantation has become a reasonable therapeutic option for Type 1 (insulindependent) diabetic patients with end-stage nephropathy who undergo kidney transplantation. Heterotopic transplantation with venous anastomosis to an iliac vein leads to insulin delivery into the systemic circulation. Since the liver normally extracts $\approx 50 \%$ of the insulin from portal blood (first-pass effect; Ferrannini and Cobelli 1987), endogenous insulin metabolic clearance in these patients is reduced. In the absence of compensatory mechanisms, this should lead to hyperinsulinaemia, which may promote the development of vascular complications (Jarrett 1988; Zavaroni et al. 1989). Hyperinsulinaemia in the basal state and after bolus injections of glucose and arginine has been described in pancreas-transplanted patients with systemic venous drainage, and was avoided by portal venous drainage (Diem et al. 1990). Venous anastomosis of the pancreas graft to the portal circulation, however, is surgically more difficult (Calne 1984; Sutherland et al. 1987) and may cause unneccessary complications.

The present study examines glucose tolerance, IRinsulin and C-peptide in the basal state and after an oral glucose challenge in nine Type 1 diabetic patients with end-stage nephropathy treated by combined transplantation of a whole cadaveric pancreas (bladder drainage of exocrine secretions) and a kidney, and in ten matched non-diabetic recipients of a kidney graft only.

\section{Subjects and methods}

Study protocol. The study protocol was approved by both the ethics committees at the Georg-August-University, Göttingen, and at the Eberhard-Karls-University, Tübingen. Informed consent was obtained from all participants.

Patients. Nine Type 1 diabetic patients (duration $24 \pm 6$ years) were studied $10 \pm 9$ months after simultaneous pancreas-kidney transplantation (exocrine drainage into the urinary bladder; systemic venous drainage into an iliac vein). Before surgery, $C$ peptide was $\leq 0.05 \mathrm{nmol} / 1$ even after stimulation with oral glucose $(100 \mathrm{~g}), \quad 30 \mathrm{~min}$ later followed by intravenous 
tolbutamide $(1 \mathrm{~g})$ and glucagon $(10 \mu \mathrm{g} / \mathrm{kg}$ body weight). These tests were performed by Dr. P.M. Müller (Department of Medicine IV, Eberhard-Karls-University, Tübingen, FRG).

The pancreas-kidney-transplanted patients were compared to ten non-diabetic kidney-transplanted patients of similar age (48 \pm 13 vs $41 \pm 9$ years in pancreas graft recipients), body mass index $\left(23.1 \pm 3.8\right.$ vs $\left.22.3 \pm 2.0 \mathrm{~kg} / \mathrm{m}^{2}\right)$ and endogenous creatinine clearance ( $54 \pm 20 \mathrm{vs} 58 \pm 20 \mathrm{ml} / \mathrm{min}$, all means $\pm \mathrm{SD}$ ).

Immunosuppressive medication included prednisone or prednisolone ( 7.5 to $30 \mathrm{mg}$ per day) and cyclosporin A (180 to $640 \mathrm{mg}$ per day) in all patients. Azathioprine ( 25 to $150 \mathrm{mg}$ per day) was used in six out of nine pancreas-kidney-transplanted patients and in five out of ten kidney-transplanted patients. The mean glucocorticoid dosage was higher by $61 \%$ (not significant) in the pancreas-transplanted group of patients, and the mean cyclosporin $A$ dose was higher by $25 \%(\mathrm{p}=0.03)$, as compared to the kidney-graft recipients.

All patients had a normal $\mathrm{Hb}{ }_{\mathrm{A} 1 \mathrm{c}}$ and were in a clinically stable situation at the time of the study.

For comparison, the results of ten previously studied healthy control subjects (age: $43 \pm 15$ years; body mass index: $23.2 \pm 1.5$ $\mathrm{kg} / \mathrm{m}^{2}$ ) are also shown.

Experimental procedures. All tests were performed in the morning after an overnight fast. The morning medication was withheld until the end of the experiment. The patient's arteriovenous shunt (Cimino fistula) was punctured with a teflon cannula. Basal blood samples were drawn over $30 \mathrm{~min}$. At -30 min, metoclopramide (13.3 $\mathrm{mg}$ ) was administered by mouth to reduce variations in gastric emptying (Thompson et al. 1982). $50 \mathrm{~g}$ oral glucose (OGT Boehringer, Mannheim, FRG) in $400 \mathrm{ml}$ water was administered at time 0 .

Blood specimens. Blood was drawn at the time points shown in Figure 1. Heparinized tubes (Sarstedt, Nümbrecht, FRG) contained aprotinin (20 000 Kallikrein inhibiting units/mi; Trasylol, $200 \mu 1$ per $10 \mathrm{ml}$ blood, Bayer AG, Leverkusen, FRG). After centrifugation, plasma aliquots were kept frozen for hormone analyses at $-30^{\circ} \mathrm{C}$.

Laboratory determinations. Glucose was measured in plasma stored with NaF (Microvette CB 300, Sarstedt, Nümbrecht, FRG) using a Glucose Analyser 2 (glucose oxidase method; Beckman instruments, Munich, FRG). Plasma IR-insulin and C-peptide were assayed using commercial radioimmunoassay kits (Insuin RIA 100, Pharmacia, Freiburg, FRG; RIA-mat C-Peptid II, BykSangtec Diagnostica, Dietzenbach, FRG) with human insulin and C-peptide as standard. The presence of insulin-bindingantibodies was excluded in all patients according to the instructions to the insulin radioimmunoassay (incubation in the absence of added anti-insulin antibody).

Calculations and statistical analysis. Experimental results are shown as mean \pm SEM. Integration was carried out according to the trapezoidal rule. Glycaemic excursions or secretory responses were analysed as incremental values over (or below) baseline values. For the analysis of insulin metabolic clearance, baseline values (IR-insulin and C-peptide) were not subtracted (area under the curve). Significances of differences were estimated using non-parametric analyses (Mann-Whitney U-test for group comparisons). To limit the problems of multiple comparisons, only mean basal, peak (60 min after oral glucose) and integrated incremental values were analysed.

\section{Results}

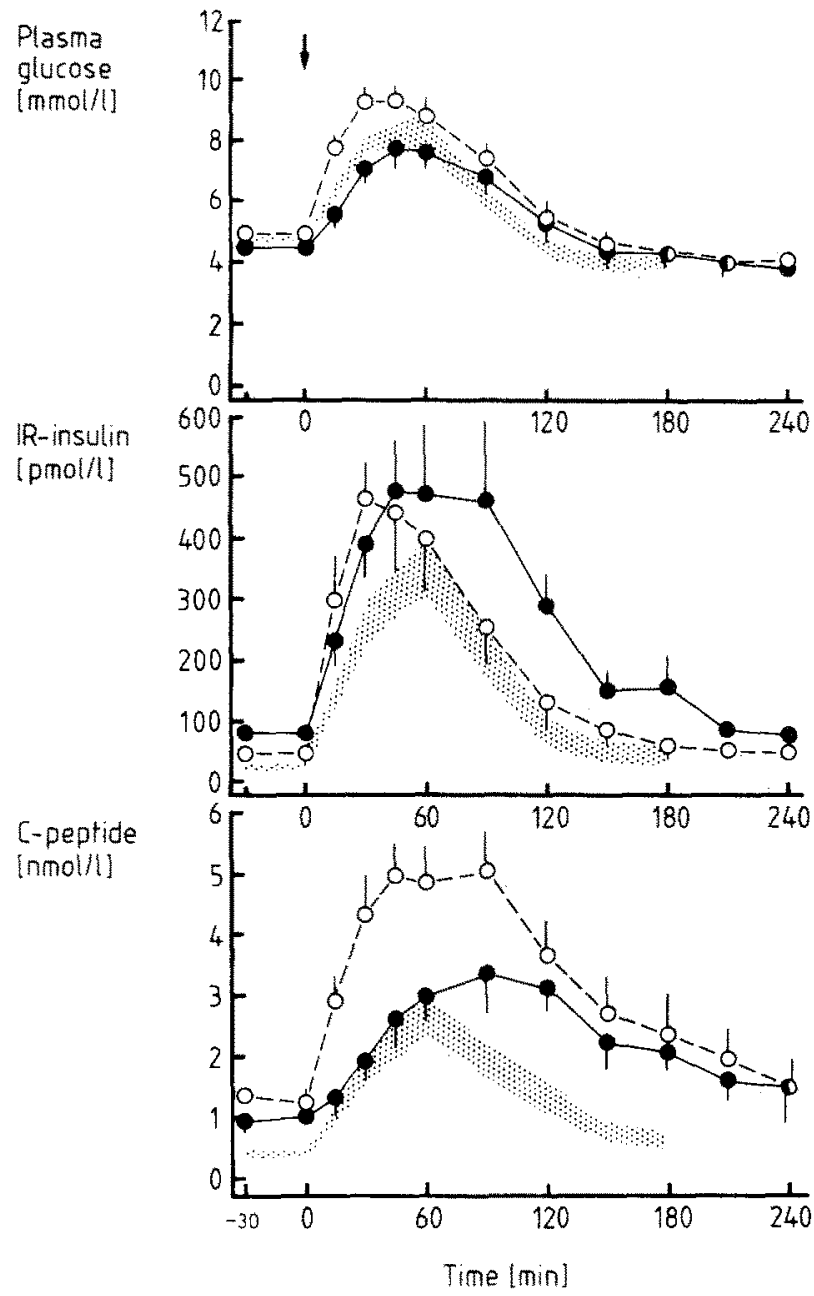

Fig. 1. Plasma glucose (upper panel), IR-insulin (middle panel) and C-peptide (lower panel) in the basal state and after a $50 \mathrm{~g}$ oral glucose challenge (arrow) in pancreas-kidney-transplanted patients ( - ), non-diabetic kidney-transplanted patients (O-O), and in healthy subjects (dotted areas). Mean \pm SEM 
Table 1. Plasma glucose, IR-insulin, and C-peptide concentrations in nine Type 1 (insulin-dependent) diabetic patients after successful combined pancreas and kidney transplantation, in ten non-diabetic kidney-transplanted patients, and in ten healthy control subjects.

\begin{tabular}{|c|c|c|c|c|c|c|}
\hline $\begin{array}{l}\text { Patient/subjec } \\
\text { Condition }\end{array}$ & Parameter & (unit) & $\begin{array}{l}\text { Pancreas-kidney- } \\
\text { transplanted } \\
\text { patients }\end{array}$ & $\begin{array}{l}\text { Non-diabetic } \\
\text { kidney-transplanted } \\
\text { patients }\end{array}$ & $\begin{array}{l}\text { Significance of } \\
\text { difference } \\
\text { (p-value) }\end{array}$ & $\begin{array}{l}\text { Normal } \\
\text { Subjects }\end{array}$ \\
\hline \multirow[t]{3}{*}{ Basal } & Glucose & $(\mathrm{mmol} / \mathrm{l})$ & $4.5 \pm 0.2$ & $5.0 \pm 0.1$ & 0.04 & $4.7 \pm 0.1$ \\
\hline & IR-insulin & $(\mathrm{pmol} / \mathrm{l})$ & $81 \pm 8$ & $50 \pm 7$ & 0.004 & $25 \pm 6$ \\
\hline & C-peptide & $(\mathrm{nmol} / \mathrm{l})$ & $1.01 \pm 0.14$ & $1.30 \pm 0.19$ & 0.14 & $0.43 \pm 0.05$ \\
\hline \multirow{3}{*}{$\begin{array}{l}\text { Peak } \\
\qquad(60 \mathrm{~min})\end{array}$} & Glucose & $(\mathrm{mmol} / \mathrm{l})$ & $7.8 \pm 0.7$ & $9.3 \pm 0.4$ & 0.089 & $8.2 \pm 0.4$ \\
\hline & IR-insulin & $(\mathrm{pmol} / \mathrm{l})$ & $480 \pm 77$ & $464 \pm 58$ & 0.50 & $349 \pm 48$ \\
\hline & C-peptide & $(\mathrm{nmol} / \mathrm{l})$ & $3.39 \pm 0.66$ & $5.06 \pm 0.61$ & 0.02 & $2.69 \pm 0.31$ \\
\hline \multirow{3}{*}{$\begin{array}{l}\text { Integrated } \\
\text { incremental } \\
\text { response }^{\mathrm{a}}\end{array}$} & Glucose & $\left(\mathrm{mmol} \mathrm{l}^{-1} \cdot \mathrm{min}\right)$ & $293.8 \pm 35.6$ & $367.0 \pm 43.5$ & 0.14 & $245.0 \pm 24.8$ \\
\hline & IR-insulin & $\left(\mathrm{nmol} \cdot 1^{-1} \cdot \min \right)$ & $44.2 \pm 6.8$ & $34.2 \pm 6.8$ & 0.051 & $25.1 \pm 4.0$ \\
\hline & C-peptide & $\left(\mathrm{nmol} 1^{-1} \cdot \min \right)$ & $322.6 \pm 47.6$ & $492.3 \pm 72.8$ & 0.036 & $191.1 \pm 27.0$ \\
\hline
\end{tabular}

Mean \pm SEM. ${ }^{\text {a }}$ : Transplanted patients 0-240 min; healthy control subjects 0-180 min.

Healthy control subjects were not included in the statistical analysis because they were examined as part of earlier studies, because blood was drawn from venous cannnulas, and because the experimental period was shorter. Their results are depicted for illustrative reasons only.

In the basal state, pancreas-kidney transplanted patients (with systemic venous insulin delivery) had significantly higher insulin and lower glucose concentrations than non-diabetic kidney transplanted patients. C-peptide values were not significantly different (Fig 1; Table 1).

Glycaemic excursions after the oral glucose load (50 g) were not significantly different. Eight out of nine pancreas-kidney-transplanted patients and eight out of ten kidney-transplanted patients had a normal oral glucose tolerance (WHO-criteria modified for a $50 \mathrm{~g}$ load; Ito et al. 1983). The remaining few patients in both groups had a slightly impaired oral glucose tolerance.

The insulin profiles after the glucose challenge were similar for both patient groups. Peak values were not different. The elevation in IR-insulin tended to last longer (by $\approx 30 \mathrm{~min}$ ) in the pancreas-kidneytransplanted patients (integrated incremental responses: $p=0.051$; borderline significance).

The incremental $\mathrm{C}$-peptide responses after oral glucose were significantly $(p=0.036)$ smaller in pancreas-transplanted patients than in kidneytransplanted patients.

Both in the basal state and after oral glucose, the molar ratio of $\mathrm{C}$-peptide over IR-insulin was significantly lower in pancreas-transplanted patients with systemic venous insulin delivery than in kidneytransplanted patients with portal-venous drainage of their functioning pancreas (Table 2).

\section{Discussion}

The results of the present study confirm that moderate hyperinsulinaemia characterizes the basal state in pancreas-transplanted patients with systemic insulin delivery (Diem et al. 1990; Osei et al. 1990). After an oral glucose challenge, however, no significant differences in glucose and IR-insulin profiles were observed between groups of pancreaskidney-transplanted patients (with systemic venous drainage of the pancreas graft) and non-diabetic kidney-transplanted patients (with portal venous drainage of their pancreas). Since C-peptide responses were significantly smaller in the pancreaskidney-transplanted patients, their lower endogenous insulin metabolic clearance (Table 2), probably due to their reduced hepatic insulin exposure, seems to be compensated for by secretion of lower amounts of insulin to the same stimulus. Similar observations have been made after a mixed meal in a comparable group of pancreas-graft recipients (Osei et al. 1990).

Since C-peptide is eliminated predominantly via the kidneys (Henriksen et al. 1987; Zavaroni et al. 1987), basal plasma C-peptide concentrations depend on kidney function (Regeur et al. 1978). Differences in C-peptide responses can, therefore, be used to deduce differences in insulin secretion between the pancreas-kidney-transplanted and the non-diabetic kidney-transplanted groups of patients, because their endogenous creatinine clearance was similar. The compensatory reduction in insulin secretion can be viewed as a meaningful adaptation. 
Table 2. Molar C-peptide over IR-insulin ratio (as an estimate of endogenous insulin metabolic clearance) in pancreas-kidney-transplanted patients (with systemic venous insulin delivery) and non-diabetic kidney-transplanted patients (portal venous insulin delivery).

\begin{tabular}{lllll}
\hline Patient/subject group & $\begin{array}{l}\text { Pancreas-kidney- } \\
\text { transplanted } \\
\text { patients }\end{array}$ & $\begin{array}{l}\text { Non-diabetic } \\
\text { kidney-transplanted } \\
\text { patients }\end{array}$ & $\begin{array}{l}\text { Significance of } \\
\text { the difference } \\
\text { (p-value) }\end{array}$ & $\begin{array}{l}\text { Healthy } \\
\text { subjects }\end{array}$ \\
\hline Basal steady-state & $12.7 \pm 1.7$ & $29.8 \pm 5.7$ & 0.0035 & $23.4 \pm 4.8$ \\
After oral glucose challenge (integrated responses) & $9.4 \pm 1.1$ & $20.3 \pm 3.1$ & 0.0045 & $9.4 \pm 0.8$ \\
\hline
\end{tabular}

Mean \pm SEM. ${ }^{\text {a }}$ : area under the curve (basal values not subtracted)

It does, therefore, not neccessarily indicate a "defect" in Beta-cell secretory responses after nutrient stimulation (Madsbad et al. 1990; Polonsky et al. 1990).

It appears that after the glucose challenge only the amount of insulin is secreted that is necessary to maintain a normal glucose tolerance. The small glycaemic excursion, indicative for the degree of glucose tolerance achieved by pancreas transplantation in the present group of previously Type 1 diabetic patients, is able to limit insulin secretion and to avoid significant post-prandial hyperinsulinaemia. Hyperinsulinaemia after a meal or after an oral carbohydrate load would then only be expected in patients with impaired or mildly diabetic glucose tolerance, as in "normal" (nontransplanted) subjects (Reaven et al. 1972).

The slight impairment of glucose tolerance observed in a small number of patients was probably due to their immunosuppressive medication. Cyclosporin A in therapeutic doses does not appear to interfere with Beta-cell function in man (Robertson et al. 1989), as observed in some laboratory animals (Helmchen et al. 1984; Stöckmann et al. 1987). Prednisone-induced insulin resistance (Pagano et al. 1983) probably is more important.

The present study confirms that also in humans insulin delivery into the portal vein (non-diabetic kidney-transplanted patients) and into the systemic circulation (pancreas-kidney-transplanted patients), when leading to comparable elevations in insulin concentrations, are equally able to maintain a normal glucose tolerance, as in animals (Botz et al. 1976; Kruszynska et al. 1985).

The question arises why there is no compensatory reduction in insulin secretion in the basal state. For an answer, one has to analyse the differences in the regulation of basal and nutrient-stimulated insulin release. Glucose concentrations are certainly important under both conditions. Only under fasting conditions, in normal subjects, insulin itself exerts a feedback control of Beta-cell secretion (DeFronzo et al. 1981). This mechanism is not active at elevated plasma glucose concentrations (Bratusch-Marrain and Waldhäusl 1985). The minimum circulating concentration of insulin that effectively lowers endogenous C-peptide (DeFronzo et al. 1981) is in the range observed in pancreas-kidney-transplanted patients in the basal state (Diem et al. 1990; Osei et al. 1990; this study). Recent evidence suggests that this insulin Beta-cell feedback inhibition at least partially depends on extrinsic pancreatic innervation (Stagner et al. 1986). It is not known whether this insulin Beta-cell feedback normally plays a role in determining basal insulin secretion rates. If this were so, a defective feedback inhibition, possibly due to denervation of the transplanted pancreas, could well contribute to basal hyperinsulinaemia in pancreastransplanted patients. In line with these considerations, Luzi et al. (1991) demonstrated that exogenous insulin failed to reduce $C$-peptide concentrations in pancreas graft-recipients.

In conclusion, only in the basal state, but not after an oral glucose challenge, pancreas-transplanted patients with systemic venous insulin delivery are characterized by moderate hyperinsulinaemia. After oral glucose, the reduced endogenous metabolic insulin clearance seems to be compensated for by a reduction in insulin secretion, as long as the elevation in glucose concentrations remains normal. A defective insulin Beta-cell feedback inhibition could possibly explain why such a compensatory reduction in insulin secretion does not occur in the basal state in patients with a denervated, transplanted pancreas.

Acknowledgements: We thank Ms. S. Bierkamp, Ms. A. Bernhard, Ms. S. Ogilvie, Ms. C. Winzker, Mrs. C. Lange, Mr. Th. Brasching, and Mr. S. Born for excellent technical assistance. This study was in part supported by B. Braun-Stiftung, Melsungen, FRG, and by the Deutsche Forschungsgemeinschaft, Bonn-Bad Godesberg, FRG, grant $\mathrm{Na}$ 203/2-1. 
Botz CK, Leibel BS, Zingg W, Gander RE, Albisser AM (1976) Comparison of peripheral and portal routes of insulin infusion by a computer-controlled insulin infusion system (artificial endocrine pancreas). Diabetes 25: 691-700

Bratusch-Marrain PR, Waldhäusl WK (1985) Suppression of basal, but not of glucose-stimulated insulin secretion by human insulin in healthy and obese hyperinsulinaemic subjects. Metabolism 34: 188-193

Calne RY (1984) Paratopic segmental pancreas grafting: a technique with portal venous drainage. The Lancet I: 595-597 DeFronzo RA, Binder C, Wahren J, Felig Ph, Ferrannini E, Faber OK (1981) Sensitivity of insulin secretion to feedback inhibition by hyperinsulinaemia. Acta Endocrinol 98: 81-86 Diem P, Abid M, Redmon JB, Sutherland DER, Robertson RP (1990) Systemic venous drainage of pancreas allografts as independent cause of hyperinsulinaemia in Type 1 diabetic recipients. Diabetes 39: $534-540$

Ferrannini E, Cobelli C (1987) The kinetics of insulin in man. II. The role of the liver. Diabetes/Metabol Rev 3: 365-397

Helmchen U, Schmidt WE, Siegel EG, Creutzfeldt W (1984) Morphological and functional changes of pancreatic $B$ cells in cyclosporin A-treated rats. Diabetologia 27: 416-419 Henriksen JH, Tronier B, Builow JB (1987) Kinetics of circulating endogenous insulin, $\mathrm{C}$-peptide and proinsulin in fasting non-diabetic man. Metabolism 36: 463-468

Ito C, Mito K, Hara H (1983) Review of the criteria for diagnosis of diabetes mellitus based on results of a follow-up study. Diabetes 28: 1039-1043

Jarrett RJ (1988) Is insulin atherogenic? (editorial).

Diabetologia 31: 71-75

Kruszynska YT, Home PD, Alberti KGMM (1985) Comparison of portal and peripheral insulin delivery on carbohydrate metabolism in streptozotocin-diabetic rats. Diabetologia 28 : 167-171

Luzi L, Battezzati A, Perseghin G, Facchini F, Vergani S, Di Carlo V, Pozza G (1991) Feedback inhibition of insulin (I) secretion in denervated pancreas. $10^{\text {th }}$ workshop of the AIDSPIT study group (abstract)

Madsbad S, Christiansen E, Andersen HB, Christensen NJ, Rasmussen K, Olgaard K, Kirkegaard P, Volund Aa, Tronier $B$, Burcharth $F$ (1990) B-cell defects after pancreas transplantation in Type 1 patients. Diabetes 39 (Suppl. 1): 15 A (abstract)

Osei K, Henry ML, O'Dorisio TM, Tesi RJ, Sommer BG, Ferguson RM (1990) Physiological and pharmacological stimulation of pancreatic islet hormone secretion in Type 1 diabetic pancreas allograft recipients. Diabetes 39: 1235-1242
Pagano G, Cavallo-Perin P, Cassader M, Bruno A, Ozzello A, Masciola P, Dall'Omo AM, Imbimbo B (1983) An in vivo and in vitro study of the mechanism of prednisone-induced insulin resistance in healthy subjects. J Clin Invest 72: 1814-1820

Polonsky K, Jaspan J, Woodle L, Thistlewaite R (1990)

Alterations in the pattern of insulin secretion and $C$-peptide kinetics post pancreas transplantation. Diabetes 39 (Suppl. 1): $15 \mathrm{~A}$ (abstract)

Reaven GM, Olefsky J, Farquhar JW (1972) Does hyperglycaemia or hyperinsulinaemia characterize the patient with chemical diabetes? Lancet I: 1247-1249

Regeur L, Faber OK, Binder C (1978) Plasma C-peptide in uraemic patients. Scand J Clin Lab Invest 38: 771-775

Robertson RP, Franklin G, Nelson L (1989) Intravenous glucose tolerance and pancreatic islet beta-cell function in patients with multiple sclerosis during 2-yr treatment with cyclosporin. Diabetes 38: 58-64

Stagner J, Samols E, Polonsky K, Pugh W (1986) Lack of direct inhibition of insulin secretion by exogenous insulin in the canine pancreas. J Clin Invest 78: 1193-1198

Stöckmann F, Fehmann HC, Göke B, Siegel EG, Creutzfeldt W (1989) Impairment of stimulated insulin release from the isolated perfused rat pancreas by cyclosporin pretreatment. Transplantation 48: 381-385

Sutherland DER, Goetz FC, Moudry KC, Abouna GM, Najarian JS (1987) Use of recipient mesenteric vessels for revascularization of segmental pancreas grafts; technical and metabolical considerations. Transplant Proc 9: 2300-2304 Thompson DG, Wingate DL, Thomas M, Harrison D (1982) Gastric emptying as a determinant of the oral glucose tolerance test. Gastroenterol 82: 51-55

Zavaroni I, Deferrari G, Lugari R, Bonora E, Garibotto G, Dall'Aglio E, Robaudo E, Gnudi A (1987) Renal metabolism of C-peptide in man. J Clin Endocrinol Metab 65: 494-498 Zavaroni I, Bonora E, Pagliara M, Dall'Aglio E, Luchetti L, Buonanno G, Bonati PA; Bergonzani M, Gnudi L, Passeri M, Reaven $G$ (1989) Risk factors for coronary artery disease in healthy persons with hyperinsulinaemia and normal glucose tolerance. $N$ Engl J Med 320: 702-706

Dr. med. M. Nauck,

Division of Gastroenterology and Endocrinology,

Department of Medicine, Georg-August-University, Robert-Koch-Strasse 40,

D-3400 Göttingen,

Germany (FRG) 